\title{
Author Correction: Placental gene expression and antibody levels of mother-neonate pairs reveal an enhanced risk for inflammation in a helminth endemic country
}

\author{
Esther Ludwig, Jutta Harder, Matthew Lacorcia, Yabo Josiane Honkpehedji, \\ Odilon Paterne Nouatin, Govert J. van Dam, Paul L. A. M. Corstjens, Erliyani Sartono, \\ Meral Esen, Silvia M. Lobmaier, Ayola Akim Adegnika \& Clarissa Prazeres da Costa
}

Correction to: Scientific Reports https://doi.org/10.1038/s41598-019-52074-z, published online 31 October 2019

The Acknowledgements section in this Article is incomplete.

"We are grateful to all pregnant women who participated in the study. We thank all CERMEL personnel for their exceptional assistance, and we are indebted to the midwives at the General Hospital and those at HAS, as well as the co-workers at CERMEL. Claudia de Dood (LUMC, Cell and Chemical Biology department) is acknowledged for preparing the UCP-LF CAA test materials and performing the CAA assays on the plasma and urine samples. This work was supported and funded by DZIF TI 07.003 and DFG CO 1469/8-1."

should read:

"We are grateful to all pregnant women who participated in the study. We thank all CERMEL personnel for their exceptional assistance, and we are indebted to the midwives at the General Hospital and those at HAS, as well as the co-workers at CERMEL. Claudia de Dood (LUMC, Cell and Chemical Biology department) is acknowledged for preparing the UCP-LF CAA test materials and performing the CAA assays on the plasma and urine samples. This work was supported and funded by DZIF TI 07.003, DFG CO 1469/8-1 and DFG CO 1469/14-1."

(i) Open Access This article is licensed under a Creative Commons Attribution 4.0 International License, which permits use, sharing, adaptation, distribution and reproduction in any medium or format, as long as you give appropriate credit to the original author(s) and the source, provide a link to the Creative Commons license, and indicate if changes were made. The images or other third party material in this article are included in the article's Creative Commons license, unless indicated otherwise in a credit line to the material. If material is not included in the article's Creative Commons license and your intended use is not permitted by statutory regulation or exceeds the permitted use, you will need to obtain permission directly from the copyright holder. To view a copy of this license, visit http://creativecommons.org/licenses/by/4.0/.

(C) The Author(s) 2020 